\title{
Multi-isotope analysis of the population of the lost medieval village of Auldhame, East Lothian, Scotland.
}

\author{
Angela L. Lamb*1, Melissa Melikian², Rachel Ives², Jane Evans ${ }^{1}$ \\ ${ }^{1}$ NERC Isotope Geosciences Laboratory, British Geological Survey, Keyworth, Nottingham \\ NG12 5GG, U.K. E-Mail: alla@bgs.ac.uk \\ ${ }^{2}$ AOC Archaeology Group, Unit 7, St. Margaret's Business Centre, Moor Mead Road, \\ Twickenham, TW1 1JS, U.K. \\ *Corresponding author
}




\begin{abstract}
This study is one of only a handful to combine strontium, oxygen, carbon, nitrogen and sulphur isotope data for medieval human remains, in this case from individuals buried in a cemetery in the remote Scottish coastal village of Auldhame, which was abandoned in the $17^{\text {th }}$ century AD. The strontium and oxygen isotope analysis of tooth enamel suggests that the group was predominantly comprised of a local, static population and thus this allows the examination of the dietary habits of a remote coastal community. The combination of relatively high nitrogen isotope values with relatively low carbon isotope values within bone collagen suggests little marine protein in the diet, which is unusual given the coastal location. The community may have been consuming some freshwater fish or omnivores (pigs fed on animal diets), but also we suggest that the combination of isotope values could be explained by soil improvement methods. Some evidence for soil deepening at the site, and by association manuring, suggests the consumption of cereals was important to the diet, and may explain the high nitrogen values found in combination with terrestrial carbon isotope values. This combination of dietary isotopes has previously been suggested to be unusual for the medieval period, but we propose it is perhaps more common than originally conceived. As there are few previous multi-isotope studies from Scottish medieval assemblages on this scale, the study provides an opportunity to construct a picture of medieval and early post-medieval life in rural Scotland.
\end{abstract}

Keywords Medieval, Scotland, population origin, paleodiet, manure, isotopes 


\section{Introduction}

The Auldhame site was discovered during ploughing in 2005 and is located on Auldhame Farm, near Tantallon Castle on the East Lothian coast of Scotland, UK (Figure 1). The foundations of a medieval church and a graveyard containing 242 burials have been excavated (Hindmarch ${ }^{1}$ ). The large number of well-preserved human skeletons provides an excellent opportunity to study the population origin and behaviour of a substantial group of individuals across the medieval and early post-medieval periods. The medieval period in Britain was a time of population influx and raids by groups including the Vikings are well established in the historical literature for this time, including in Lothian (Webster ${ }^{2}$ ). This study aims to utilise a suite of isotopes to firstly investigate the population composition of the village (strontium and oxygen isotopes) and secondly to examine their dietary behaviour (carbon, nitrogen and sulphur isotopes). Previous paleodietary findings from medieval samples have examined the impact of religious practises (Müldner and Richards ${ }^{3}$ ), the age of weaning in medieval Britain (Richards ${ }^{4}$; see further Fogel $^{5}$; Fuller ${ }^{6}$ ), sexspecific differences in diet (Richards ${ }^{7}$ ) and whether individuals settled in marginal communities were able to diversify and include marine fish in their diet (Richards ${ }^{7}$ ). Sulphur isotopes are becoming increasingly utilized as an additional tool for bone dietary studies (e.g. Richards ${ }^{8,9}$;

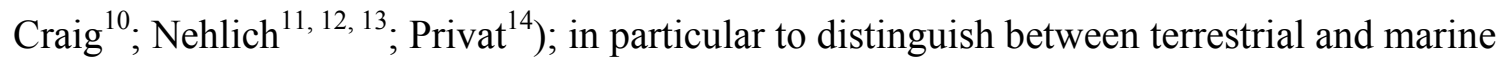
based diets. The data derived from the current study will contribute further knowledge to dietary practices of a marginal rural medieval settlement and explore whether or not there were any clear population influxes. As there are few previous applications of isotope analyses to Scottish medieval assemblages (Stevens ${ }^{15}$; Richards ${ }^{4}$ ), the current study also makes an important contribution to the expanding corpus of data that can inform on the dietary background from a Scottish perspective. This study combines $\mathrm{Sr}, \mathrm{O}, \mathrm{C}, \mathrm{N}$ and $\mathrm{S}$ isotope data for individuals from Auldhame and thus provides an opportunity to build up a picture of medieval life in rural Scotland.

\section{Background to Isotopic Analyses}

Over the past 20 years, isotope analysis has become a widely used tool in archaeology for assessing the origin and movements of animals. The premise is based on known geographical 
variations in stable and radiogenic isotopes (e.g. Richards ${ }^{7}$; Montgomery ${ }^{16}$; Price $^{17}$ ). Oxygen and strontium isotopes are fixed in enamel biogenic phosphate at the time of tooth formation. Biogenic phosphate is extremely robust and the isotopic signature of enamel does not normally change during life, nor is it altered in the burial environment. Initially research focused on strontium isotopes $\left(\right.$ Ericson $^{18}$; Price ${ }^{19}$ ), which are now increasingly analysed in parallel with phosphate-bound oxygen (Fricke ${ }^{20}$; Evans ${ }^{21}$; Chenery $^{22}$; Schwarcz $^{23}$ ). Strontium isotopes are derived from both solid and liquid foods and relate to the soil-derived bio-available strontium which, in the absence of any surficial deposits such as peat, loess, tills etc., is related to the geology of the area where the food was produced (see Price ${ }^{17}$ for review). Oxygen isotopes incorporated into living organisms are derived primarily from ingested fluids and reflect the isotopic value of available meteoric, ground or drinking water. The oxygen isotope composition of meteoric water will primarily be determined by global water cycles (Dansgaard ${ }^{24}$ ) and processes such as evaporation and condensation; thus they vary systematically with latitude (Dansgaard ${ }^{24}$; Darling ${ }^{25}$ ). Hence, oxygen isotope ratios should, therefore, provide proxy data for place of origin (Darling ${ }^{26}$; Fricke and $\mathrm{O}^{\prime} \mathrm{Neil}^{27}$; Longinelli ${ }^{28}$ ). As strontium and oxygen isotopes behave independently of one another, they allow two parameters for investigating an individual's place of origin and migration patterns.

Palaeodietary reconstruction is based on the principle that the isotopic composition of consumed food (dietary proteins, carbohydrates and lipids) is transformed by the body and preserved in animal tissues (e.g. bone collagen, hair, and dentine) $\left(\right.$ Sealy $\left.^{29}\right)$. For carbon isotopes, animal tissues will reflect the $\delta^{13} \mathrm{C}$ values of the plants and animals consumed (plus fractionation) and the distinction in $\delta^{13} \mathrm{C}(\sim 12 \%)$ that exists between the two major plant photosynthetic groups can be observed within these tissues $\left(\mathrm{C}_{4}=-15 \%\right.$ to $-9 \%$, $\mathrm{C}_{3}=-33 \%$ o to $-23 \%$ o $)\left(\mathrm{O}^{\prime}\right.$ Leary $\left.{ }^{30}\right)$. In the UK, and indeed most of Europe, natural C4 plants do not exist and were predominantly introduced to northern Europe in the post-medieval period in the form of sugar cane and cereals such as maize (Mays ${ }^{31,32}$ ). Carbon isotopes have instead been used to indicate the existence of marine food in the diet compared to terrestrially sourced food. Data analysed in previous investigations have determined models that suggest a diet comprising of $100 \%$ marine protein would result in collagen carbon isotope value of $-12 \pm 1 \%$ and a diet composed of $100 \%$ terrestrial resources would yield a carbon (C3) isotope value of $-20 \pm 1 \%$ (Fischer ${ }^{33}$; Mays ${ }^{34}$; 
Richards ${ }^{7}$ ). The carbon and nitrogen isotope ratio from human bone collagen can be modelled using bi-variate discrimination diagrams of carbon and nitrogen isotopes to constrain dietary inputs and regimes that can reflect on marine and terrestrial protein consumption (e.g. Richards $^{7}$ ). A trophic level effect or small amount of positive fractionation (by 3-5\% for $\delta^{15} \mathrm{~N}$ and $<1 \%$ for $\delta^{13} \mathrm{C}$ ) will occur throughout the levels of the food chain and can be indicative of certain groupings to aid dietary reconstruction (see DeNiro and Epstein ${ }^{35}$ ). Nitrogen isotope ratios preserved in animal tissues also depend largely on diet (predominantly protein), but environmental and metabolic factors (such as water and food stress or soil nitrogen cycling) are also influential $\left(\right.$ Heaton $\left.^{36}\right) . \delta^{15} \mathrm{~N}$ values will primarily reflect the vegetation at the base of the food chain and then incorporate a step-wise increase through each trophic level, thus carnivores will have $\delta^{15} \mathrm{~N}$ values about +3 to $+5 \%$ o higher than those of herbivores from the same ecosystem and thus it is often possible to assess the proportion of meat in the diet (Schoeninger and DeNiro ${ }^{37}$ ). Both $\delta^{13} \mathrm{C}$ and $\delta^{15} \mathrm{~N}$ may enrich in weaning infant mammals due to the trophic level increase that is produced as a result of consuming maternal milk (Jenkins ${ }^{38}$ ). By analysing herbivore collagen, it is possible to estimate the $\delta^{13} \mathrm{C}$ and $\delta^{15} \mathrm{~N}$ ratios of the baseline vegetation of an archaeological site, but in their absence, baseline values have to be assumed. Most terrestrial plants have $\delta^{15} \mathrm{~N}$ values of $\sim 0-5 \%$, thus herbivores might expect to have values of $\sim 4-9 \%$, and carnivores $\sim 8-13 \%$. Marine and terrestrial diets can also be distinguished as marine food chains are often longer than terrestrial ones, resulting in relatively higher $\delta^{15} \mathrm{~N}$ values through more trophic level increases (Schoeninger and DeNiro ${ }^{37}$ ). Freshwater fish in the diet are more difficult to ascertain from carbon and nitrogen isotopes as they will give similar $\delta^{13} \mathrm{C}$ and $\delta^{15} \mathrm{~N}$ ratios to terrestrial mammals in the diet. The addition of sulphur isotopes may allow freshwater fish in the diet to be discriminated more easily within bone collagen.

Sulphur isotopes are a relatively new application to palaeodietary studies and thus their interpretation in relation to diet is less well understood. They have been used in conjunction with carbon and nitrogen studies largely, to distinguish marine and terrestrial food sources $\left(\right.$ Richards $^{9}$; Privat $^{14}$ ). There is only a minor offset between $\delta^{34} \mathrm{~S}$ in diet and the consumer $\left(\sim 1.5 \%\right.$; Richards $\left.{ }^{8,9}\right)$ through trophic levels. In contrast there is a large range in $\delta^{34} \mathrm{~S}$ from terrestrial to marine ecosystems. Marine primary producers have $\delta^{34} \mathrm{~S}$ values between 17 to $21 \%$ reflecting marine sulphates in contrast to terrestrial organisms which have much lower, more 
variable, values reflecting the underlying soil processes $\left(-7\right.$ to $+8 \%$; Nriagu and Coker ${ }^{39}$; Krouse $^{40}$ ). Additionally, sea-spray and marine precipitation can have an effect on coastal ecosystems, by introducing marine sulphates and thus resulting in much higher $\delta^{34} \mathrm{~S}$ soil and vegetation values within at least $20 \mathrm{~km}$ of the coast $\left(\mathrm{Chukhrov}^{41} ; \mathrm{McArdle}^{42}\right.$; $\mathrm{Coulson}^{43}$ ). Dietary $\delta^{34} \mathrm{~S}$ will reflect the sulphate composition of the substrate of the primary organisms (Peterson and Fry ${ }^{44}$ ) and thus also has the potential to identify 'non-locals' in a population if there is supporting baseline sulphate information (e.g. Craig ${ }^{45}$ ). More recently sulphur isotopes have been used to identify freshwater fish in human diets where the baseline $\delta^{34} \mathrm{~S}$ values for riverine sulphates could be established and were sufficiently different to terrestrial values (Nehlich ${ }^{11,12}$, Privat $^{14}$ ).

\section{Materials}

Excavations in 2005 at the settlement of Auldhame, East Lothian, Scotland, identified a burial ground associated with a small chapel (Figure 1). A total of 242 skeletons were excavated. The cemetery was in use for approximately 1000 years between the $7^{\text {th }}$ century and the early $17^{\text {th }}$ century. The population sample provides an insight into a settlement that had fallen out of use and become lost sometime during the $17^{\text {th }}$ century AD. A programme of radiocarbon dating has defined four phases of burial activity although not all burials can be defined to a phase $\left(\right.$ Hindmarch $^{1}$ ). Phase 1 of the burial ground is dated 650-1000 AD. This phase is represented by the development of a monastic settlement at the site and the burials from this date are assumed to be associated with this settlement. Eighteen burials were dated to this phase. Phase 2 is dated to 1000-1200 AD and burial at the site continued apparently in relation to a functioning chapel at the site. Eleven burials were related to this phase. Phase 3 dates to 1200-1400 AD and includes nine burials. The number of burials at the site is thought to be in decline during and towards the end of this phase. Phase 4 is represented by only four dated burials, all juveniles, and is dated to 1500-1700 AD. The latter phase appears to be associated with the acquisition of the Auldhame estate by Adam Otterburn in the early $16^{\text {th }}$ century. Additional buildings were constructed over the previous chancel. 
The period spanning the cemetery use at Auldhame witnessed numerous changes in population migrations and immigrations into and throughout Scotland. During the 5-7th centuries AD Germanic and Celtic tribes from Ireland as well as Anglians moved into Scotland in various waves settling in areas such as Strathclyde. From the 8th to 10th centuries, recurrent waves of Scandinavian settlers arrived into Shetland, Fair Isle, Orkney and the Western Isles of Scotland $\left(\right.$ Webster $^{2}$; Barrell $\left.{ }^{46}\right)$. During the 9th century, Lothian and the east were predominantly controlled by Anglian aristocracy who maintained close links with those settled in Northumbria $\left(\right.$ Webster $^{2}$; Barrell ${ }^{46}$; MacQuarrie ${ }^{47}$ ). Local kingdoms grew in the north such as that of Alba, controlled by unified Picts and Scots, which provided significant support to Lothian when challenged by Norse invading settlers. Further challenges to Lothian are documented by the Danish ruled kingdom of York as well as by attempted expansion of the kingdom of Wessex during the 10th century $\left(\mathrm{Webster}^{2}\right)$. Textual evidence indicates that border conflicts continued throughout the period 1296-1603 AD and Lothian was particularly affected by repeated attempts at conquest made by Scottish kings such as Malcolm II in 1018 AD (Webster ${ }^{2}$; Barrell ${ }^{46}$; MacQuarrie ${ }^{47}$; Foard and Partida ${ }^{48}$ ). During the 13th century a temporary abandonment of Auldhame is documented as having occurred with subsequent movement of the chapel to a more inland location due to raids carried out by King Edward I of England (Hindmarch ${ }^{1}$ ).

\section{Demographic Background}

The 242 human burials from Auldhame consisted of 161 adults (67\%) and 81 sub-adults (33\%). The coastal location and date of the village occupation indicated the potential for population influx or evidence of migration to exist in the sample. A random selection of 50 individuals testing $20 \%$ of the population sample was undertaken based on individuals with good skeletal completeness and preservation and individuals that could be tightly constrained to a burial phase. The osteology of the fifty samples is presented in Table 1 and the demographic profile of the burials is presented in Table 2 . The mortality profile indicates there were a low number of neonate and infant deaths in the sample. The prevalence of neonate or foetal deaths is $5 \%$ $(11 / 242)$ when expressed as a percentage of the total sample and $15 \%(11 / 73)$ of the total aged juvenile sample. The remainder of the sub-adult profile shows a relatively consistent mortality 
trend with only a slight peak evident for those aged 6-11 years at death. Young individuals are often expected to have suffered premature death as the developing immune system may not be able to withstand illnesses. Burials from this group appear under-represented at Auldhame. As is the case in many cemetery excavations, the burial assemblage from Auldhame does not represent a complete sample of the original buried population. It is possible that specific areas of the cemetery were retained for the burial of infants and young children, which did not fall within the limits of the excavation. A comparative medieval assemblage from a rural cemetery which spanned 950-1850 AD at Wharram Percy, North Yorkshire, demonstrated that infants below the age of 18 months were buried in an area on the north side of the church (Mays ${ }^{34}$ ). A detailed comparison of the juvenile demographic profile compared to contemporary sites is beyond the scope of this paper but is presented in Hindmarch ${ }^{1}$. The majority of adults were dying aged 2635 years representing $26 \%$ of the total adult sample and $36-45$ years representing $28 \%$ of the total adult sample. Individuals had survived into old age in the Auldhame sample with $17 \%$ (22/127) of the aged adult sample having reached old adulthood.

The analytical assemblage consisted of 58 adult males or probable males and 42 adult females or probable females. A total of 10 adults were classed as indeterminate sex. The Auldhame assemblage shows a slight bias with a sex ratio of 1.3:1 in favour of males. A 1:1 ratio is to be expected in any 'normal' population where sex is simply governed by genetic factors. The difference in numbers of male and female burials is not however, statistically significant $\left(\mathrm{Chi}^{2}=\right.$ 1.71 (df1), $\mathrm{p}=0.191)$. Of the fifty random samples subjected to isotopic investigation, 19 derived from females and 12 derived from males. Individuals of probable sex were grouped with those of more strongly determined sex for this analysis. The difference in sample size between the sexes is not statistically significant $\left(\mathrm{Chi}^{2}=0.65(\mathrm{dfl}), \mathrm{p}=0.420\right)$ and is therefore unlikely to exert any influence in sex-specific trends in the data.

Of relevance to the isotope interpretation, the local bedrock geology of this area of coastal East Lothian is dominated by rocks of the Carboniferous period and the bedrock is Carboniferous Limestone with a large area of andesitic/basaltic volcanic rocks nearby. To the south, the Southern Uplands are dominated by Palaeozoic meta-sedimentary rocks, and to the North, beyond the Devonian deposits, the older Scottish Proterozoic rocks outcrop. 


\section{Methods}

\section{Isotope Analysis}

Analysis of carbon $\left(\delta^{13} \mathrm{C}\right)$, nitrogen $\left(\delta^{15} \mathrm{~N}\right)$ and sulphur $\left(\delta^{34} \mathrm{~S}\right)$ isotopes were carried out on rib bone from 50 individuals. Oxygen and strontium isotopes were analysed in dental enamel from M2 molars from 16 individuals. For enamel samples, a section of crown surface was abraded from the surface to a depth of $>100 \mu \mathrm{m}$ using a tungsten carbide dental bur and the removed material discarded. A thin slice of enamel was then cut from the tooth using a flexible diamondedged rotary dental saw. All sawn surfaces were mechanically cleaned with a tungsten carbide bur, and any adhering dentine was removed.

\section{Strontium Isotopes}

Enamel samples for strontium isotope analysis were transferred to a clean (class 100, laminar flow) working area for further preparation. The enamel pieces were first cleaned ultrasonically in high purity water to remove dust, rinsed twice, dried down in high purity acetone and approximately $25 \mathrm{mg}$ of the cleaned enamel was weighed into pre-cleaned Teflon beakers. A known amount of ${ }^{84} \mathrm{Sr}$ tracer solution was added to each sample which was dissolved in Teflon distilled $16 \mathrm{M} \mathrm{HNO}_{3}$. The sample was converted to chloride using Quartz distilled in $6 \mathrm{M} \mathrm{HCl}$ and then taken up in $2.5 \mathrm{M} \mathrm{HCl}$. Strontium was collected using conventional, Dowex ${ }^{\circledR}$ resin ion exchange methods. Strontium was loaded onto a single Re Filament with TaF following the method of Birck $^{49}$ and the isotope composition and concentrations were determined by Thermal Ionisation Mass spectroscopy (TIMS) using a Finnigan Triton multi-collector mass spectrometer. The international standard for ${ }^{87} \mathrm{Sr} /{ }^{86} \mathrm{Sr}$, NBS987, gave a value of $0.710284 \pm 10(\mathrm{n}=20,2 \sigma)$ for static analysis. All strontium ratios have been corrected to a value for the standard of 0.710250 . Blank values were in the region of $100 \mathrm{pg}$.

\section{Oxygen Isotopes}


Small fragments of clean enamel $(15-20 \mathrm{mg})$ were treated to solubilise $\mathrm{PO}_{4}$ anions and precipitated as silver phosphate, using a method adapted from $\mathrm{O}^{\prime} \mathrm{Neil}^{50}$. The fragments of enamel were cleaned in concentrated hydrogen peroxide for 24 hours to remove organic material and subsequently evaporated to dryness. The samples were then dissolved in $2 \mathrm{M}$ nitric acid and transferred to clean polypropylene test tubes. Each sample was then treated with $2 \mathrm{M}$ potassium hydroxide for neutralization and $2 \mathrm{M}$ hydrofluoric acid to remove calcium from the solution by precipitation of calcium fluoride. The samples were then centrifuged and the supernatant added to beakers containing ammoniacal silver nitrate solution and heated gently to precipitate silver phosphate. The silver phosphate was filtered, rinsed, dried and weighed into silver capsules for analysis. Oxygen isotope measurements on each sample were analysed in triplicate by continuous flow isotope ratio mass spectrometry (TC/EA-CFIRMS) using the method of Vennemann $^{51}$. The instrumentation is comprised of a TC/EA (high temperature conversion elemental analyser) coupled to a Delta ${ }^{\text {Plus }} \mathrm{XL}$ isotope ratio mass spectrometer via a ConFlo III interface (Thermo Finnigan, Bremen, Germany). The reference material NBS120c, calibrated against certified reference material NBS127 (assuming $\delta^{18} \mathrm{O}$ of NBS127 $=+20.3 \%$ versus SMOW; IAEA ${ }^{52}$ ), has an accepted value of $21.70 \%$ (Chenery ${ }^{22}$ ). The reproducibility of NBS120C during this set of analyses was $21.64 \% \pm 0.26(1 \sigma, n=54) . \delta^{18} O$ analyses were done in triplicate and the average standard deviation of the triplicates was $\pm 0.09 \%$. Drinking water values are calculated using Levinson's equation (Levinson ${ }^{53}$ ), after correction for the difference between the average published values for NBS120c used at NIGL and the value for NBS120b used by Levinson. ACC-1, a commercially available hydroxyapatite (Aldrich), converted to $\mathrm{Ag}_{3} \mathrm{PO}_{4}$, was also used as a batch control with a reproducibility of $\pm 0.14 \%$ o $(1 \sigma)$.

\section{Collagen Extraction and Methods of Carbon, Nitrogen and Sulphur Isotope Analysis}

Collagen was extracted using a modified Longin method $\left(\right.$ Brown $\left.^{54}\right)$. Approximately $0.5-1.0 \mathrm{~g}$ of bone was cleaned and covered with $8 \mathrm{ml}$ of cold $0.5 \mathrm{M} \mathrm{HCl}$ to demineralise. The remaining solid collagen was rinsed and solubilised in a solution of $\mathrm{pH} 3 \mathrm{HCl}$ at $70^{\circ} \mathrm{C}$ in a hot block for 48 hours. The solutions were then filtered using an $8 \mu \mathrm{m}$ Ezze filter to remove solids before freeze drying. Two aliquots from each collagen sample were weighed into small tin capsules for analysis with 
additional $\mathrm{V}_{2} \mathrm{O}_{5}$ to aid combustion of the sulphur. Analysis of carbon, nitrogen and sulphur isotopes was by Continuous Flow Isotope Ratio Mass Spectrometry (CFIRMS). The instrumentation is comprised of an Elemental analyser (Flash/EA) coupled to a Thermo Finnigan Delta $^{\text {Plus }} \mathrm{XL}$ isotope ratio mass spectrometer via a ConFlo III interface. Collagen carbon, nitrogen and sulphur isotope ratios $\left(\delta^{13} \mathrm{C}, \delta^{15} \mathrm{~N}\right.$ and $\left.\delta^{34} \mathrm{~S}\right)$ are reported in per mil (\%o) relative to VPDB, AIR and VCDT standards respectively. $\delta^{13} \mathrm{C}$ and $\delta^{15} \mathrm{~N}$ ratios were calibrated using an inhouse reference material M1360p (powdered gelatine from British Drug Houses) with expected delta values of $-20.32 \%$ (calibrated against $\mathrm{CH} 7$, IAEA) and $+8.12 \%$ (calibrated against $\mathrm{N}-1$ and N-2, IAEA) for $\mathrm{C}$ and $\mathrm{N}$ respectively. $\delta^{13} \mathrm{C}$ and $\delta^{15} \mathrm{~N}$ analyses were done in triplicate and the average standard deviation of the triplicates was $\delta^{15} \mathrm{~N}= \pm 0.11 \%$ and $\delta^{13} \mathrm{C}= \pm 0.05 \%$. $\delta^{34} \mathrm{~S}$ ratios were calibrated using an in-house reference material BROC-2 (powdered broccoli) with expected delta values of $11.67 \%$ (calibrated against S-1 and S-2, IAEA). $\delta^{34}$ S analyses were done in duplicate and the average standard deviation of the duplicates was $\pm 0.12 \%$. The $1 \sigma$ reproducibility for mass spectrometry controls for these analyses were $\delta^{15} \mathrm{~N}= \pm 0.12 \%, \delta^{13} \mathrm{C}= \pm$ $0.15 \%$ and $\delta^{34} \mathrm{~S}= \pm 0.20 \%$ respectively.

\section{Results}

\section{Population Origins}

The data from the strontium and oxygen analysis are presented in Figure 2 and Table 3 . The tooth enamel samples range between $\mathrm{Sr}$ concentrations of 75-178 ppm with an isotope range of $0.70875-0.71354$ (Figure 2). The village of Auldhame is situated close to the coast in an area of Carboniferous geology which includes both limestone and volcanic rocks $\left(\mathrm{BGS}^{55}\right)$. The best estimates for the $\mathrm{Sr}$ isotope ranges for these lithologies are shown on Figure 2. The Carboniferous Limestone data has a relatively well defined range of $0.7092 \pm 0.0002$ (2 s.d., $\mathrm{n}=11$, sample type $=$ plants) and the Carboniferous Volcanic rocks record some of the lowest strontium isotopes biosphere values in Britain $0.7085 \pm 0.0008(n=4,2$ s.d., sample type $=$ various $\left(\right.$ Evans $\left.^{21}\right)$. The Auldhame cemetery is founded on the volcanic rocks and the dentine samples from the site record values in or close to this range 0.7086 and 0.7083 . Both have elevated Sr concentrations (351 \& 370ppm) typical of diagenetic Sr uptake. The Palaeozoic 
rocks of the Southern Uplands crop out about $15 \mathrm{~km}$ south of Auldhame. There is little biosphere data currently available for these rock types but, by analogy with similar aged Welsh rocks $\left(\right.$ Evans $\left.^{21}\right)$ these are assigned values between 0.711 and 0.713 .

Consequently all the individuals in this study can be assigned as "local" to within a $15 \mathrm{~km}$ range of Auldhame, with one possible exception: AULD-SK 158 has an ${ }^{87} \mathrm{Sr} /{ }^{86} \mathrm{Sr}$ ratio of 0.71354 . This individual spent their childhood in a more radiogenic setting, and a value of 0.71354 is typically derived from Palaeozoic or older rocks, or granites. Although the closest source of such rocks would be the Palaeozoic sequences of the Southern Uplands, it is beyond the range hypothesized for these rocks and is more consistent with the areas of more radiogenic biosphere strontium in the areas of Perthshire and Aberdeenshire to the north

The oxygen isotope data from Auldhame ranges from $\delta^{18} \mathrm{O}=16.5$ to $18.3 \%$ with only one predominant outlier at 19.0\% (AULD-SK 327). This presents a relatively normal data distribution with $\delta^{18} \mathrm{O}=17.4 \pm 1.4 \% 0(2 \sigma, \mathrm{n}=15)$ for all the data, and $17.3 \pm 1.1 \%$ o $(2 \sigma, \mathrm{n}=14)$ if the outlying sample AULD-SK 327 is excluded. The range of $\delta^{18} \mathrm{O}$ drinking water values (excluding AULD-SK 327) is -9.3 to $-5.4 \%$. Within the British Isles, $\delta^{18} \mathrm{O}$ drinking water values range broadly from $-4 \%$ in the extreme west to $-9 \%$ in the north east inland regions $\left(\right.$ Darling $^{25}$ ). Thus the majority of individuals could have come from the local area or within the UK. The mean value of $17.3 \%$ converts to an average drinking water range for this population of $-7.5 \%$, which is consistent with drinking water values for the Lothian area of Scotland ( -7 to $-8 \%$; Darling ${ }^{25}$ ). Two individuals (AULD-SK 318, AULD-SK 352) have equivalent drinking water values of $-9.3 \%$, which suggest an origin in a colder location than eastern Scotland. In Europe, -9 to $-10 \%$ drinking water values are found in central Europe and Scandinavia, to the east of Denmark. The oxygen isotope data are combined with strontium isotope ratios (Figure 2) and the field of local values is defined by our knowledge of local strontium fields (Evans $\left.{ }^{56}\right)$. The majority of data (adults and children) form a coherent group with two outliers caused by high strontium isotope ratios (AULD-SK 158) and high $\delta^{18} \mathrm{O}$ values (AULD-SK 327). The data support the interpretation from the strontium data that most of the individuals sampled could come from the Lothian area of Scotland. Sample SK 327 is interpreted as potentially part of the local population due to its $\mathrm{Sr}$ isotope data. The unusually high $\delta^{18} \mathrm{O}$ value of $+19.0 \%$ from this 
individual would however, convert to a drinking water value of $-3.9 \%$ which is outside the range of average British drinking water values and is more typical of a warmer, more Mediterranean environment.

\section{Paleodietary Results}

The carbon, nitrogen and sulphur isotope results from the sample are shown in Tables 4-7; Figures 3-6. The collagen atomic $\mathrm{C} / \mathrm{N}$ ratios fall into the expected range for well-preserved bone (2.9-3.6; DeNiro ${ }^{57}$ ), apart from two individuals (AULD-SK 104 and AULD-SK 426), which fall just outside of this range (Table 4 ) and these 2 values are excluded from further discussion. Criteria for assessing sulphur preservation in collagen are less well established but Nehlich and Richards ${ }^{13}$ suggested that atomic C/S ratios between 300-900 and atomic N/S ratios between 100-300 were indicative of well-preserved collagen. Of the 11 individuals selected for sulphur analysis, all fall within these ranges (Table 5).

The range of $\delta^{13} \mathrm{C}$ and $\delta^{15} \mathrm{~N}$ data from Auldhame is similar to previously published data from other Northern English medieval human populations (Müldner and Richards ${ }^{3,57}$; Richards ${ }^{4}$ ). $\delta^{13} \mathrm{C}$ values for the population average $-19.6 \pm 0.7 \%$ ( 1 S.D.) and for $\delta^{15} \mathrm{~N}$ are $12.3 \pm 1.0 \%$ ( 1 S.D.). The mean results of the analysis are presented in relation to the individuals where an age group could be identified (Table 6). The infant burial (AULD-SK 825) has relatively low $\delta^{13} \mathrm{C}$ and $\delta^{15} \mathrm{~N}$ values (-21.5\%o and $10.9 \%$ ) compared to the other individuals, which place it entirely in the terrestrial zone. However, the juvenile data from Auldhame are based on very small sample sizes; therefore little certainty can be offered for interpretations of the composition of childhood diets from the isotope results. The only significant difference in mean carbon results across the adult age ranges is the relatively high value of $-17.5 \%$ for the $26-35$ age group (Table 6), otherwise there are no clearly detectable age-related differences in adult dietary composition. There is little evidence for a sex-based difference in the carbon isotopic signature between adults in the sample who could be sexed (19/31 females and 11/31 males), mean male $\delta^{13} \mathrm{C}=-20.0 \%$; mean female $\delta^{13} \mathrm{C}=-19.2 \%$. 
The highest nitrogen values in the Auldhame sample derive from the 2 juveniles aged 6-11 years (Table 6). The small number of samples from juveniles restricts any definite interpretations, although it is of interest that the youngest 2 infants do not have particularly high $\delta^{15} \mathrm{~N}$ values. Previous investigations have indicated that breast-feeding infants are likely to have increased nitrogen isotope signals relative to older children and adults due to a trophic effect caused by consumption of maternal supplies (see further Fogel ${ }^{5}$; Fuller ${ }^{6}$ ). There are no statistically significant differences identifiable in the mean nitrogen results across the adult age range or between the sexes (Table 6), mean male $\delta^{15} \mathrm{~N}=11.9 \%$; mean female $\delta^{15} \mathrm{~N}=12.6 \%$.

Sulphur isotope ratios vary from 8.2 to $15.7 \%$ with overlapping means when comparing males (average 13.9 \pm 0.1 ) and females (average 13.6 \pm 0.2 ) (Tables 5-6, Figure 5). The overall average of the 11 individuals for $\delta^{34} \mathrm{~S}$ is $13.8 \pm 0.1 \%$ and this is compared to other coastal and inland medieval sites in Europe (Figure 6).

When the isotope results are considered by each phase of cemetery use, it is evident that there are no notable changes in the mean isotope results over time, although the small number of individuals radiocarbon dated meant that this could not be confirmed with statistical testing (Table 7). There is no clear evidence to indicate a change in the local strontium and oxygen isotopes throughout the period of use, further confirming that there were no large-scale changes to the structure of the local population through time. In addition, there does not appear to be any change in the composition of the local diet through time.

\section{Discussion}

\section{The Population Composition}

The strontium and oxygen isotope analysis from Auldhame demonstrates that the group was largely comprised of a local population. The strontium isotope signals from tooth enamel are reflective of a childhood origin and growth local to the Lothian region. As the samples were taken from adults, the results either indicate that little migration away from Lothian had occurred during adult life, or else may suggest that adults returned to their local church shortly before death and for burial. The population may not have remained wholly static during the period of 
cemetery use as migration out of the settlement may have occurred and would not be detectable by the analysis of those who had remained. There is however, very little evidence to suggest that large fluxes of individuals migrated into the local population at Auldhame from areas with detectable and different isotopic signatures.

Despite the population movements and challenges evident in the historical evidence, the isotopic analysis has demonstrated that the population sample from the rural Scottish settlement at Auldhame was predominantly local. Only one individual from the adult sample was identified as an outlier to the strontium isotope model, which suggests an origin elsewhere other than Lothian. This individual (AULD-SK 158) derived from a region with Palaeozoic or older rocks or granites, which is likely to indicate areas of the Southern Uplands or areas of Perthshire and Aberdeenshire to the north of Lothian, a finding also supported by the stable oxygen isotope analysis. One clear outlier was identified in the oxygen isotope data. This individual (AULD-SK 327 ) is posited as local to the area of Lothian by its strontium value but may have been recognised as different to the remainder of the sample based on the water supply utilised. Drinking water values are based on the assumption that the main source of water into the body is from an unaltered rainwater source, either directly, or from aquifers. If for some reason such a source is not the main water intake (e.g. breast-feeding infants) the value can become modified. The individual may have come from a warmer climate where the $\mathrm{Sr}$ isotope systematics are indistinguishable from those in Lothian. Alternatively, the individual could be a random statistical outlier in the population sample. It is also possible that the water intake of this individual was modified in some way so that it did not conform to the typical model of unmodified UK water source. The oxygen isotope results indicated that two individuals (AULD-SK 318, AULD-SK 352) had drinking water equivalents potentially indicative of central European or Scandinavian values. In contrast, the strontium results for these individuals were within local ranges. It is not clear whether broad similarities in strontium isotope signals between Scandinavia and Eastern Scotland may complicate the differentiation of non-local individuals that may be highlighted by the oxygen isotope data. Interestingly in this regard, was AULD-SK 752, who was identified as of likely local origin to Lothian by the $\mathrm{Sr}$ and $\mathrm{O}$ analysis but who was found buried with Viking finds including a spear head, spurs, horse tack (buckle and strap end) $\left(\right.$ Hindmarch $\left.^{1}\right)$. Given the isotope signals for this individual, it is plausible that the burial 
represents a second generation of Viking settlers at Auldhame. These outliers are discussed below in terms of the dietary evidence.

\section{Dietary Reconstruction}

Recent historical syntheses of medieval diets are largely specific to the English perspective (eg. Drummond and Wilbraham ${ }^{58}$; Hammond ${ }^{59}$; Woolgar $^{60}$; Brears $^{61}$; but see Ewan ${ }^{62}$ ). Diets contained meat ranging from beef, pork or lamb (Woolgar ${ }^{63}$, as well as fruit, vegetables, legumes such as beans and peas, and fish (see Hammond ${ }^{59}$ ). Freshwater and marine fish were consumed and included herrings, mullet, plaice, whiting, haddock, mackerel, milwell, ling and eels, as well as shellfish: oysters, mussels, cockles and winkles (Hammond ${ }^{59}$; Serjeantson and Woolgar $^{64}$ ). Hammond ${ }^{59}$ suggests that the diet of those living in the country in medieval England largely comprised of carbohydrates, mostly grains such as barley and oats that were baked into breads or brewed into ales (also Stone ${ }^{65}$ ). Protein in meat and eggs was consumed less often, but dairy foods including cheese were used as well as soured milk curds, as well as some fruits and vegetables such as beans and onions, leeks, cabbage, garlic $\left(\right.$ Hammond $\left.^{59}\right)$.

Recent paleodietary studies have made significant contributions towards the understanding of the composition of the medieval diet, principally from the analysis of stable isotopes of carbon and nitrogen (Mays ${ }^{31}$; Müldner and Richards ${ }^{3}$; Müldner and Richards ${ }^{57}$ ). The findings have demonstrated the role that marine protein contributed to the medieval diet in some areas but not all (see in particular Richards ${ }^{4,7}$; Müldner and Richards ${ }^{3}$ ). Several studies have suggested that the increasing adoption of religious trends of fasting and meat avoidance on certain days following Bennedictine practice is likely to have contributed to the greater inclusion of fish in the diet (Müldner and Richards ${ }^{3}$ ). The Auldhame individuals have relatively high $\delta^{15} \mathrm{~N}$ values compared to other UK medieval sites but as they are combined with largely terrestrial $\delta^{13} \mathrm{C}$ signatures, do not suggest a significant amount of marine fish in the diet (Figure 3). As we do not have access to any faunal data at Auldhame this interpretation is based on comparisons with other Medieval coastal sites, discussed further below (Richards ${ }^{4,7}$; Müldner and Richards ${ }^{3}$. Mays and Beavan ${ }^{66}$ ). 
In order to contextualise the results further, the data are compared with published data from medieval populations from five sites in Northern England: Brompton Bridge, Warrington and Towton (Müldner and Richards ${ }^{3}$ ), Wharram Percy (Richards ${ }^{4}$ ), and Fishergate Priory, York (Müldner and Richards ${ }^{57}$ ); and a multi-age site from Orkney: Newark Bay (Richards ${ }^{7}$ ) (Figure 4). Data fields for cattle and freshwater and marine fish from Müldner and Richards ${ }^{3}$, although not ideal for this study, are also included in the absence of faunal data from Auldhame. The Auldhame data define overlapping fields with the other medieval sites from Northern England apart from Wharram Percy which has lower $\delta^{15} \mathrm{~N}$ values and is interpreted as indicative of a mixed plant/animal diet with no marine influence. In contrast to Auldhame, Newark Bay individuals show relatively high $\delta^{13} \mathrm{C}$ and $\delta^{15} \mathrm{~N}$ values and suggest a marine component to the diet for some individuals, particularly the men (Richards $\left.{ }^{7}\right)$. The mean $\delta^{13} \mathrm{C}$ value for the Auldhame individuals is $-19.6 \%$ which is considerably lower than for other published northern eastern English coastal medieval communities (e.g. -18.2\%o Hartlepool and-18.6\% Newcastle), where some marine fish in the diet was inferred (Mays ${ }^{34}$ ). Müldner and Richards ${ }^{3}$ suggested that the combination of largely terrestrial $\delta^{13} \mathrm{C}$ values combined with high $\delta^{15} \mathrm{~N}$ values ( $>11 \%$ ) was highly unusual for medieval England and suggested little or no marine dietary inputs. Muldner and Richards ${ }^{3}$ suggested along with a terrestrial plant component, a dietary component of either omnivore consumption (pigs fed on animal diets) or freshwater fish was likely.

The addition of a selected group of sulphur isotope analysis may help shed light on the Auldhame isotope profile. Six males and five females were analysed, with no difference in the results evident between the sexes. The sulphur isotope ratios varied from 8.2 to $15.7 \%$ with an average of $13.8 \pm 2.2 \%$ (Figures 5,6). AULD-SK 452 has a much lower $\delta^{34} \mathrm{~S}$ value compared to the other $10(8.2 \%)$ and if this is removed, the mean becomes $14.3 \pm 1.4 \%$. Previous sulphur isotope studies on coastal communities have recorded $\delta^{34} \mathrm{~S}$ values of the order of $15-22 \%$, suggesting the influence of sea-spray on a terrestrial diet and/or marine protein consumption, with inland communities having dietary $\delta^{34} \mathrm{~S}$ ratios of $1-14 \%$ ( Richards $^{9}$ ). Very high collagen $\delta^{34} \mathrm{~S}$ values ( 20-22\%o), alongside marine $\delta^{13} \mathrm{C}$ values were recorded from individuals from Cnip, Orkney (U.K.) which have been used to indicate marine resource use (Figure 6). There is evidence of seaweed (kelp) manuring at this site which would infer the addition of marine sulphates to the soil and explain the very high $\delta^{34} \mathrm{~S}$. Lower Sr concentrations suggest the 
individuals from Auldhame, were not using kelp as a fertilizer (see Evans ${ }^{56}$ ). Most of the $\delta^{34} \mathrm{~S}$ values for Auldhame collagen are above 14\%o (Figure 5), a little lower than what has been recorded for coastal sites (Figure 6) but may reflect more typical coastal values for areas where the prevailing wind is off-shore as in the east coast of Scotland (prevailing wind is from a SW direction). The lack of $\delta^{13} \mathrm{C}$ evidence for much marine fish in the diet at Auldhame could suggest that the $\delta^{34} \mathrm{~S}$ values reflect atmospheric marine sulphates in the substrate or freshwater fish. There are several freshwater bodies in close proximity to Auldhame and it is possible that they were accessing such forms of protein. As we don't have $\delta^{34} \mathrm{~S}$ values for riverine sulphates from the region it is difficult to assess this possibility further and more investigations into site specific baseline values of sedimentary sulphates, soils and manure are needed to fully understand the sulphur signal from this site.

Another factor worth considering may be the use of manuring on the land around the site. In particular, a recent study by Bogaard ${ }^{67}$ explored the variability inherent in nitrogen isotopes caused by the effects of manuring on land destined for crop cultivation or grazing. The use of animal dung manure may add residual ammonium enriched with ${ }^{15} \mathrm{~N}$ to the soil which can be converted into nitrate with high $\delta^{15} \mathrm{~N}$ values that is taken up by plants as the source of nitrogen used in the biosynthesis of plant amino-acids (see Bogaard ${ }^{67}$; as well as Van Klinken ${ }^{68}$; Holliday ${ }^{69}$ ). The experimental study by Bogaard ${ }^{67}$ identified an increase of $3 \%$ in the trophic effect on nitrogen isotopes in manured grains of winter wheat. As such, Bogaard ${ }^{67}$ found that diets largely based in cereal grains could erroneously indicate an isotopic signal typically representative of a largely animal based or mixed animal and cereal based diet. Data reported in Van Klinken ${ }^{68}$ also allude to the effect that manuring may have in influencing ${ }^{15} \mathrm{~N}$ consumed in the human diet.

Farming formed a significant part of the lifestyle and food procurement in rural contexts as well as for the supply of growing towns (Franklin ${ }^{70}$; Gies and Gies ${ }^{71}$; Dyer ${ }^{72}$ ). Lothian has been considered to be a rich agricultural area (e.g. Webster ${ }^{2}$ ). This interpretation is likely to have derived from the considerable arable productivity that was demonstrated by lands immediately surrounding Edinburgh, which was awarded burgh status and central seat of government under 
David II (Webster ${ }^{2}$; MacQuarrie ${ }^{47}$ ), and thus may not be representative of Lothian as a whole. MacQuarrie $^{47}$ refers to carts sent from Lothian as well as the Southern Uplands to wellestablished burghs such as Berwick in order to obtain supplies such as corn and ale. Less is known regarding farming practices and productivity in more rural contexts in Lothian. A recent study of land management in a late medieval/post-medieval Scottish town of Nairn to the east of Inverness identified a significant increase in soil depth (up to one metre deep) on land surrounding the town, which was predominantly used for agriculture (Davidson ${ }^{73}$ ). Turf, flooring material or livestock bedding enriched with animal dung was frequently spread on cultivated land, forming deep and enriched plaggen soils. This practice is known to have occurred from the twelfth century from across Northern Europe (Gies and Gies ${ }^{71}$ ). Soil samples from the cultivated and deepened fields at Nairn contained high mineral matter, organic residues of excrement, carbonised particles and high phosphorous content $\left(\right.$ Davidson $^{73}$ ). Micromorphology soil analysis from Auldhame characterised the normal soil type as sandy brown calcareous soils prone to drought, which would have been unsuitable for cultivation without manuring to improve soil fertility and water maintenance. Soils at the site had been deepened in a similar manner to those at Nairn, and samples further demonstrated a high organic content with charcoal and coal inclusions as well as probable grass phytoliths $\left(\mathrm{AOC}^{74}\right)$. These changes are indicative of extensive manuring undertaken to improve soil fertility. This analysis suggests that without such intervention, sustained cultivation and therefore settlement occupation at Auldhame is unlikely to have been possible. In the medieval period seaweed was often used as a source of manuring in coastal locations (Dyer ${ }^{72}$; Hammond ${ }^{59}$ ). To date, only one palaeodietary investigation has questioned whether there are any isotopic effects of manuring with seaweed or further effects from coastal locations affected by sea spray, particularly on nitrogen isotope results (Richards ${ }^{7}$ ). Richards ${ }^{7}$ found slightly elevated sheep/goat nitrogen ratios in their study of faunal and human samples from Orkney which could be explained by enrichment in grazing land affected by sea spray. Similarly elevated levels of nitrogen isotopes were not however identified in cattle values in Orkney. This could imply that cattle were farmed further away from coastal locations. If Bogaard's ${ }^{67}$ results are extractable across situations in which intensive manuring is demonstrable, and is indicated in the sheep/goat data from Orkney, then there is potential for the interpretation of the dietary nitrogen isotope composition to be skewed in favour of a marine dietary 
component rather than indicative of enhanced nitrogen uptake from cereals in the diet. Unfortunately, as we don't have faunal data from the site we cannot distinguish between increased nitrogen isotope ratios from manuring consumed through cereal consumption or through the consumption of animals fed on manured crops or their by-products.

Several individuals were identified as outliers in the strontium and oxygen data and may be of non-local origin or have unusual grave goods (AULD SK-752). Most of these individuals were included in the batch of $\delta^{34}$ S analyses (AULD-SK 158, 327, 752). AULD-SK 327, an 18-25 year old female, was identified as unusual within the sample population due to her high $\delta^{18} \mathrm{O}$ ratio, suggesting perhaps a southern European childhood origin. This individual also has the highest $\delta^{13} \mathrm{C}$ value of the fifty analysed and a relatively high $\delta^{15} \mathrm{~N}$ value, indicating perhaps a more marine based diet. Her $\delta^{34} \mathrm{~S}$ value of 11.9 is also relatively high. Thus she may be a more recent immigrant if both childhood origin and more recent diet appear different to the local population. Interestingly, AULD-SK 752, who was identified as of likely local origin to Lothian by the Sr and $\mathrm{O}$ analysis but who was found buried with Viking finds, does not have unusual dietary isotope values compared to the local population. $\operatorname{Her} \delta^{13} \mathrm{C}$ and $\delta^{15} \mathrm{~N}$ values are intermediate in terms of this group, but she does have the highest $\delta^{34} \mathrm{~S}$ ratio (15.5) suggesting coastal dwelling. The idea that the burial represents a second generation of Viking settlers at Auldhame is supported by the fact that her diet concurs with the 'local' group. The individual with the more radiogenic Sr value compared to the defined 'local' group (AULD-SK 158) has a $\delta^{34}$ S ratio close to the group average but, interestingly has the second highest $\delta^{13} \mathrm{C}$ ratio and the joint highest $\delta^{15} \mathrm{~N}$ value, adding to the suggestion that this individual may be an immigrant to the area with a more marine based diet, in this case, from further north.

\section{Conclusions}

As there is a paucity of archaeological evidence for medieval rural settlements in Scotland, the multi-isotope data set presented here allows an insight into the life and diet of a largely sedentary population. The strontium and oxygen isotope analysis from Auldhame tooth enamel 
demonstrates that the group was predominantly comprised of a local, static population and this allows insight into the diet of a population predominantly unaffected by outside influences. Given the close locality of the settlement of Auldhame to the coast, and the seemingly increasing reliance on fish in the medieval diet, one may assume that high nitrogen isotopes in the bone indicate a marine contribution to the diet. However, the largely terrestrial carbon isotope signature suggests that this is not the case. Evidence for soil deepening, and by implication manuring, at the site suggests the population were consuming cereals or animal products enhanced with nitrogen due to manuring practices. The combination of relatively low $\delta^{13} \mathrm{C}$ and high $\delta^{15} \mathrm{~N}$ values, previously suggested by Richards ${ }^{7}$ to be unusual for the medieval period, we suggest is perhaps more widespread than originally thought. We suggest that if communities were using soil improvement techniques then this may explain the combination of low $\delta^{13} \mathrm{C}$ and high $\delta^{15} \mathrm{~N}$ values in some cases. Alternatively, the community may have been consuming freshwater fish. Sulphur isotopes presented here show the effect of sea-spray on the substrate around the settlement but a lack of baseline information precludes an assessment of the inclusion of freshwater fish to the diet and this requires further investigation.

The combination of multi-isotope analyses of individuals allows both a local population and any outliers to be examined in more detail. The locals defined as having a childhood origin from the region (within $30 \mathrm{~km}$ ) also had a relatively similar, constrained diet to each other in the last few decades of their life. In terms of the outliers examined, several individuals do seem to be of likely childhood immigrant status as their more recent diet is similar to the local population, yet their childhood origin isotopes $(\mathrm{Sr}, \mathrm{O})$ are unusual. Likewise some individuals had very different childhood origin isotopes and similar dietary isotopes $(\mathrm{C}, \mathrm{N}, \mathrm{S})$ to the local group, perhaps indicating they were recent immigrants or visitors. A multi-isotope approach does facilitate a more in depth analysis of a populations' origins than possible with 1 or 2 isotope element approaches and warrants wider application in archaeological investigations.

\section{Acknowledgements}

We thank Neil Boulton (NERC Isotope Geosciences Laboratory) for assistance with the chemical preparation and testing of the strontium samples. We are grateful to Graeme Carruthers 
and Jonathan Moller, AOC Archaeology for Figure 1. We also thank Historic Scotland for funding the Auldhame excavation and the subsequent program of research and publication. Carolyn Chenery is thanked for her advice on the paper.

\section{References}

1 E. Hindmarch. Living and Dying at Auldhame, East Lothian; the Excavation of an Anglian Monastic Settlement and Medieval Parish Church. Society of Antiquaries of Scotland. Unpublished work.

2 B. Webster. Medieval Scotland. The Making of an Identity. 1997. Basingstoke, MacMillan.

3 G. Müldner, M. P. Richards. Fast or Feast: Reconstructing Diet in Later Medieval England by Stable Isotope Analysis. J. Arch. Sci. 2005, 32, 39-48.

4 M. P. Richards, S. Mays, B. T. Fuller. Stable Carbon and Nitrogen Isotope Values of Bone and Teeth Reflect Weaning Age at the Medieval Wharram Percy Site, Yorkshire, UK. American Journal of Physical Anthropology, 2002, 119, 205-210.

5 M. Fogel, N. Tuross, D. W. Owsley. Nitrogen isotope tracers of human lactation in modern and archaeological populations. Annual report of the Geophysical Laboratory, 1989, Carnegie Institution of Washington, 111-117.

6 B. T. Fuller, J. L. Fuller, D. A. Harris, R. E. M. Hedges. Detection of breastfeeding and weaning in modern human infants with carbon and nitrogen stable isotope ratios, American Journal of Physical Anthropology, 2006, 129, 279-293.

7 M. P. Richards, B. T. Fuller, T. I. Molleson. Stable Isotope Paleodietary Study of Humans and Fauna from the Multi-Period (Iron Age, Viking, Late Medieval) Site of Newark Bay, Orkney. J. Arch. Sci., 2006, 33,122-131.

8 M. P. Richards, B. T. Fuller, M. Sponheimer, T. Robinson, L. Ayliffe. Sulphur isotopes in palaeodietary studies: a review and results from a controlled feeding experiment. Int. J. Osteoarchaeol. 2003, 13, 37-45.

9 M. P. Richards, B. T. Fuller, R. E. M. Hedges. Sulphur isotopic variation in ancient bone collagen from Europe: implications for human palaeodiet, residence mobility and modern pollutant studies. Earth and Planetary Science Letters, 2001, 191, 185-190.

10 O. E. Craig, M. Biazzo, A. C. Colonese, Z. Di Giuseppe, C. Martinez-Labarga, D. Lo Vetro, L. Lelli, F. Martín. Stable isotope analysis of Late Upper Palaeolithic humans and fauna remains from Grotta del Romito (Cosenza), Italy. J. Arch. Sci. 2010, 37, 2504-2512. 
11 O. Nehlich, B. T. Fuller, C. Smith, M. Jay, A. Mora, R. A. Nicholson, M. P. Richards. Application of sulphur isotope ratios to examine weaning patterns and freshwater fish consumption in Roman Oxfordshire, U.K. Geochim. Cosmochim. Acta. 2010, 75, 4963 4977.

12 Nehlich, O., Boric, D., Stefanovic, S., Richards, M. P. 2010. Sulphur isotope evidence for freshwater fish consumption: A case study from the Danube Gorges, SE Europe. Journal of Archaeological Science. 37, 1131-1139.

13 O. Nehlich, M. P. Richards. Establishing collagen quality criteria for sulphur isotope analysis of archaeological bone collagen. Archaeological and Anthropological Sciences 2009, 1, 59-75.

14 K. L. Privat, T. C. O'Connell, R. E. M. Hedges. The distinction between freshwater-and terrestrial-based diets: methodological concerns and archaeological applications of sulphur stable isotope analysis. J. Arch. Sci., 2007, 34, 1197-1204.

15 T. Stevens, M. Melikian, S. J. Grieve. Excavations at an Early Medieval Cemetery at Stromess, Orkney. Proceedings of the Society of Antiquaries of Scotland, 2005, 135, 371393.

16 J. Montgomery, J. A. Evans, T. Neighbour. Sr isotope evidence for population movement within the Hebridean Norse community of NW Scotland. Journal of the Geological Society. 2003, 160, 649-653.

17 T. D. Price, J. H. Burton, R. A. Bentley. The characterisation of biologically-available strontium isotope ratios for investigation of prehistoric migration. Archaeometry, 2002, 44, 117-135.

18 J. E. Ericson. Strontium isotope characterization in the study of prehistoric human ecology. Journal of Human Evolution, 1985, 14, 503-514.

19 T. D. Price, J. H. Burton, P. D. Fullagar, L. E. Wright, J. E. Buikstra, V. Tiesler. Strontium isotopes and the study of human mobility in ancient Mesoamerica. Latin American Antiquity, 2008, 19, 167-180.

20 H. C. Fricke, W. C. Clyde, N. Lynnerup. Oxygen isotope composition of human tooth enamel from medieval Greenland: linking climate and society. Geology 1995, 23, 869-872.

21 J. A. Evans, J. Montgomery, G.Wildman, N. Boulton. Spatial variations in biosphere ${ }^{87} \mathrm{Sr} /{ }^{86} \mathrm{Sr}$ in Britain. Journal of the Geological Society, 2010, 167, 1-

22 4C. Chenery, G. Muldner, J. Evans, H. Eckardt, M. Lewis. Strontium and stable isotope evidence for diet and mobility in Roman Gloucester, UK. J. Arch. Sci. 2010, 37, 150.

23 H. P. Schwarcz, C. D. White, F. J. Longstaffe. Stable and Radiogenic Isotopes in Biological Archaeology: Some Applications. Isoscapes 2010, 3, 335-356. 
24 W. Dansgaard. Stable isotopes in precipitation. Tellus. 1964, 16, 436.

25 W. G. Darling, A. H. Bath, J. C. Talbot. The O \& H stable isotopic composition of fresh waters in the British Isles. Hydrology \& Earth System Sciences. 2003, 7, 183-195.

26 W. G. Darling. Hydrological factors in the interpretation of stable isotopic proxy data present and past: a European perspective. Quat. Sci. Rev. 2004, 23, 743-770.

27 H. C. Fricke, J. R. O’Neil. Inter- and intra-tooth variation in the oxygen isotope composition of mammalian tooth enamel phosphate: Implications for palaeoclimatological and palaeobiological research. Palaeogeog. Palaeoclimat. Palaeoecol. 1996, 126, 91.

28 A. Longinelli. Oxygen isotopes in mammal bone phosphate: a new tool for paleohydrological and paleoclimatological research? Geochim. Cosmochim. Acta. 1984, 48, 385-390.

29 J. Sealy. Body tissue chemistry and palaeodiet. In: D. R. Brothwell, A. M. Pollard (eds) Handbook of Archaeological Sciences, 2001, 269-279. London, Wiley \& Sons.

30 M. H. O'Leary. Carbon isotopes in photosynthesis. BioScience 1988, 38, 328-333.

31 S. Mays. The human remains. In: S. Mays, C. Harding, C. Heighway. Wharram. A Study of Settlement on the Yorkshire Wolds. The Churchyard. 2007. York, York University Archaeological Publications 13, 77-192.

32 S. Mays. New Directions in the Analysis of Stable Isotopes in Excavated Bones and Teeth. In: M. Cox, S. Mays. Human Osteology In Archaeology and Forensic Science. London, Greenwich Medical Media Ltd., 425-438.

33 A. Fischer, J. Olsen, M.P. Richards, J. Heinemeier, A.E. Sveinbjörnsdóttird, P. Bennike. Coast-inland mobility and diet in the Danish Mesolithic and Early Neolithic: evidence from stable isotope values of humans and dogs. J. Arch. Sci., 2007, 34, 2125-2150.

34 S. Mays. Carbon Stable Isotope Ratios in Mediaeval and Later Human Skeletons from Northern England. J. Arch. Sci. 1997, 24, 561-567.

35 M. J. DeNiro, S. Epstein. Influence of diet on the distribution of carbon isotopes in animals. Geochim. Cosmochim. Acta. 1978, 42, 495-506.

36 T. H. E. Heaton, J. C. Vogel, G. von la Chevalerie, G. Collett. Climatic influence on the isotopic composition of bone nitrogen. Nature, 1986, 322, 822-823.

37 M. J. Schoeninger, M. J. DeNiro. Nitrogen and carbon isotopic composition of bone collagen from marine and terrestrial animals. Geochim. Cosmochim. Acta. 1984, 48, $625-$ 639. 
38 S. G. Jenkins, S. T. Partridge, T. R. Stephenson, S. D. Farley, C. T. Robbins. Nitrogen and carbon isotope fractionation between mothers, neonates, and nursing offspring. Oecologia, 2001. 129, 336-341.

39 J. O. Nriagu, R. D. Coker. Isotopic composition of sulfur in precipitation within the Great Lakes basin. Tellus, 1978, 30, 365-375.

40 H. R. Krouse. Sulfur Isotope Studies of the Pedosphere and Biosphere. In: P.W. Rundel, J.R. Ehleringer, K.A. Nagy (Eds), Stable Isotopes in Ecological Research, 1989. SpringerVerlag, NY, 424-444.

41 F. V. Chukhrov, L. P. Ermilova, V. S. Churikov, L. P. Nosik. The isotopic composition of plant sulfur. Org. Geochem. 1980, 2, 69-75.

42 N. McArdle, P. Liss, P. Dennis. An isotopic study of atmospheric sulphur at three sites in Wales and at Mace Head, Eire. J. Geophys. Res., 1998, 103(D23), 079-31.

43 J. P. Coulson, S. H. Bottrell, J. A. Lee. Recreating atmospheric sulphur deposition histories from peat stratigraphy: Diagenetic conditions required for signal preservation and reconstruction of past sulphur deposition in the Derbyshire Peak District, UK, Chem. Geol. 2005, 218, 223-248.

44 B. J. Peterson, B. Fry. Stable isotopes in ecosystem studies. Annual Review of Ecology and Systematics 1987, 18, 293-320.

45 O. E. Craig, R. Ross, S. H. Andersen, N. Milner, G. N. Bailey. Focus: sulphur isotope variation in archaeological marine fauna from northern Europe. J. Arch. Sci. 2006, 33, 1642-1646.

46 A. D. M. Barrell. Medieval Scotland. 2000. Cambridge, Cambridge University Press.

47 A. MacQuarrie. Medieval Scotland. Kingship and Nation. 2004. Stroud, Sutton Publishing Ltd.

48 G. Foard, T. Partida. Scotland's Historic Fields of Conflict. 2005. The Battlefields Trust.

49 J. L. Birck. Precision K-Rb-Sr Isotopic Analysis - Application to Rb-Sr Chronology. Chem. Geol. 1986, 56, 73-83.

50 J. R. O’Neil, L. J. Roe, E. Reinhard, R. E. Blake. A rapid and precise method of oxygen isotope analysis of biogenic phosphate. Israel Journal of Earth Science, 1994, 43, 203-212. 
51 T. W. Vennemann, H. C. Fricke, R. E. Blake, J. R. O'Neil, A. Colman. Oxygen isotope analysis of phosphates: a comparison of techniques for analysis of $\mathrm{Ag}_{3} \mathrm{PO}_{4}$. Chem. Geol, 2002, 185, 321.

52 International Atomic Energy Agency 2004. AQCS. Reference Materials Catalogue.

53 A. A. Levinson, B. Luz, Y. Kolodny. Variations in Oxygen Isotope Compositions of Human teeth and Urinary stones. Applied Geochemistry, 1987, 2, 367-371.

54 T. A. Brown, D. E. Nelson, J. S. Vogel, J. R. Southon. Improved collagen extraction by modified Longin method. Radiocarbon 1988, 30, 171-7.M. J. DeNiro. Postmortem preservation and alteration of in vivo bone collagen isotope ratios in relation to paleodietary reconstruction. Nature 1985, 317, 806-809.

55 British Geological Survey online geology maps 2012: http://maps.bgs.ac.uk/geologyviewer_google/googleviewer.html

56 J. A. Evans, N. Stoodley, C. A. Chenery. A strontium and oxygen isotope assessment of a possible 4th century immigrant population in a Hampshire cemetery, southern England. $J$. Arch. Sci., 2006, 33, 265-272.

57 G. Müldner, M. P. Richards. Diet and Diversity at later medieval Fishergate: the isotopic evidence. American Journal of Physical Anthropology. 2007, 134, 162-174.

58 J. C. Drummond, A. Wilbraham. The Englishman's Food: Five Centuries of English Diet. 1991. Pimlico Books, 496 pp.

59 P. Hammond. Food and Feast in Medieval England. 2005. Stroud, Sutton Publishing.

60 C. M. Woolgar. Meat and Dairy Products in Late Medieval England. In: C. M. Woolgar, D. Serjeantson, T. Waldron (eds). Food in Medieval England. Diet and Nutrition. 2006, Oxford, Oxford University Press, 88-101.

61 P. C. D. Brears. Cooking and dining in medieval England. 2008. Prospect Books, 512 pp.

62 E. Ewan. Town Life in the Fourteenth Century. 1990. Edinburgh: Edinburgh University Press.

63 C. M. Woolgar, D. Serjeantson, T. Waldron (eds). Food in Medieval England. Diet and Nutrition. 2006. Oxford, Oxford University Press, 88-101.

64 D. Serjeantson, C. M. Woolgar. Fish Consumption in Medieval England. In: C. M. Woolgar, D. Serjeantson, T. Waldron (eds). Food in Medieval England. Diet and Nutrition. 2006. Oxford, Oxford University Press, 102-130. 
65 D. J. Stone. The Consumption of Field Crops in Late Medieval England. In: C. M. Woolgar, D. Serjeantson, T. Waldron (eds). Food in Medieval England. Diet and Nutrition. 2006. Oxford, Oxford University Press, 11-26.

66 S. Mays, N. Beavan. An investigation of diet in early Anglo-Saxon England using carbon and nitrogen stable isotope analysis of human bone collagen. J. Arch. Sci. 2012, 39, 867874.

67 A. Bogaard, T.H.E. Heaton, P. Poulton, I. Merbach. The Impact of Manuring on Nitrogen Isotope Ratios in Cereals: Archaeological Implications for the Reconstruction of Diet and Crop Management Practices. J. Arch. Sci. 2007, 34, 335-343.

68 G. J. Van Klinken, M. P. Richards, R. E. M. Hedges. An Overview of Causes for Stable Isotopic Variations in Past European Human Populations. Environmental, Ecophysiological and Cultural Effects. In: S. H. Ambrose, M. A. Katzenberg (eds). Biogeochemical Approaches to Paleodietary Analysis. 2000. New York, Kluwer Academic/Plenum Publishing, 39-63.

69 V. T. Holliday. Soils in Archaeological Research. 2004. New York, Oxford University Press.

70 T. B. Franklin. A History of Scottish Farming. 1952. London: Thomas Nelson and Sons Ltd.

71 F. Gies, J. Gies. Life in a Medieval Village. 1991. New York, Harper Perennial.

72 C. Dyer. Making a Living in the Middle Ages. The People of Britain 850-1520. 2002. New Haven: Yale University Press.

73 D. Davidson, G. Dercon, M. Stewart, F. Watson. The Legacy of Past Urban Waste Disposal on Local Soils. J. Arch. Sci. 2006, 33, 778-783.

74 AOC. Analysis Report for Soil Micromorphology. 2008. Unpublished report for AOC Archaeology Group. 


\section{List of Figures}

Figure 1. Site location of the village of Auldhame, Lothian, Scotland.

Figure $2 .{ }^{87} \mathrm{Sr} /{ }^{86} \mathrm{Sr}$ vs $\delta^{18} \mathrm{O}_{\text {VSMOw }}$ of the Auldhame tooth enamel samples highlighting the two main outlying samples AULD SK 158 and 327. The figure includes typical ranges for local bedrock geology $\left(\right.$ Evans $\left.^{21}\right)$.

Figure 3. $\delta^{13} \mathrm{C}_{\mathrm{VPDB}}$ vs $\delta^{15} \mathrm{~N}_{\mathrm{AIR}}$ of the Auldhame bone collagen samples.

Figure $4 . \delta^{13} \mathrm{C}_{\mathrm{VPDB}}$ vs $\delta^{15} \mathrm{~N}_{\mathrm{AIR}}$ of the Auldhame bone collagen samples compared with data from Northern English Medieval human populations, a multi-age Orkney assemblage and various faunal data (data from Müldner and Richards ${ }^{3,57}$; Richards ${ }^{4,7}$ ).

Figure $5 . \delta^{34} \mathrm{~S}_{\mathrm{CDT}}$ vs $\delta^{15} \mathrm{~N}_{\mathrm{AIR}}$ composition of the Auldhame bone collagen samples.

Figure $6 . \delta^{13} \mathrm{C}_{\mathrm{PDB}}$ vs $\delta^{34} \mathrm{~S}_{\mathrm{CDT}}$ composition of the Auldhame bone collagen samples compared with data from coastal and inland human populations of varying ages (data from Richards ${ }^{9}$ ).

\section{List of Tables}

Table 1. Information on individuals analysed from Auldhame including macroscopic observations of pathological alterations. Phases of burial are assigned according to radiocarbon dating as outlined in the text. Ages in years unless specified. Adult is specified where remains could not be accurately aged. Sex abbreviations: $\mathrm{M}=$ male, $\mathrm{PM}=$ probable male, $\mathrm{F}=$ female, $\mathrm{PF}=$ probable female, Indet=indeterminate sex, Undet $=$ undetermined sex where of unsuitable age or preservation existed.

\begin{tabular}{|c|c|c|c|l|}
\hline $\begin{array}{c}\text { AULD-SK } \\
\text { Skeleton }\end{array}$ & Phase & Age & Sex & Paleopathological Findings \\
\hline 11 & & $36-45$ & M & Bilateral osteochondritis dissecans distal femora \\
\hline 74 & & $36-45$ & PF & No pathology \\
\hline 104 & Phase 1 & AD & IND & No pathology \\
& & & & \\
\hline 120 & Phase 2 & $46+$ & F & No pathology \\
\hline 140 & & $26-35$ & F & Sacral laminae partially fused \\
\hline 158 & Phase 2 & $26-35$ & F & Degenerative joint changes rib facets \\
\hline 182 & & $18-25$ & F & No pathology \\
\hline 190 & & $36-45$ & IND & No pathology \\
& & & & \\
\hline 216 & Phase 1 & $46+$ & F & Sharp force trauma cranium \\
\hline 219 & Phase 1 & $18-25$ & PM & No pathology \\
\hline
\end{tabular}




\begin{tabular}{|c|c|c|c|c|}
\hline 273 & Phase 2 & $26-35$ & $\mathrm{M}$ & No pathology \\
\hline 289 & Phase 1 & $26-35$ & $\mathrm{M}$ & No pathology \\
\hline 293 & Phase 1 & $46+$ & $\overline{\mathrm{PF}}$ & $\begin{array}{l}\text { Healed midshaft fracture right radius. Healed } \\
\text { fracture rib. Healed anterior fracture and fusion } \\
\text { thoracic T8-T9. Fracture and collapse centrum } \\
\text { lumbar L5. Probable osteoporosis in vertebral } \\
\text { pathology }\end{array}$ \\
\hline 299 & & $36-45$ & IND & $\begin{array}{l}\text { DJD } 4^{\text {th }} \text { left hand phalanx. Healed oblique } \\
\text { fracture shaft } 3^{\text {rd }} \text { digit proximal phalanx. } \\
\text { Heterotrophic ossification traumatic }\end{array}$ \\
\hline 318 & Phase 2 & $26-35$ & IND & $\begin{array}{l}\text { Kleippel feil syndrome - fusion bodies cervical } \\
\text { C2-C3. Additional fusion T4-T5 }\end{array}$ \\
\hline 321 & Phase 1 & $36-45$ & IND & No pathology \\
\hline 327 & Phase 3 & $18-25$ & $\mathrm{~F}$ & No pathology \\
\hline 345 & & $26-35$ & $\mathrm{M}$ & No pathology \\
\hline 352 & Phase 1 & $12-17$ & $\mathrm{PM}$ & No pathology \\
\hline 394 & Phase 1 & $26-35$ & IND & No pathology \\
\hline 426 & Phase 3 & $36-45$ & UN & Healed fracture right distal fibula \\
\hline 429 & & $26-35$ & IND & No pathology \\
\hline 452 & & $36-45$ & $\mathrm{M}$ & $\begin{array}{l}\text { Fusion of } 3 \text { phalanges in } 3^{\text {rd }} \text { digit - trauma related } \\
\text { subluxation and ankylosis }\end{array}$ \\
\hline 467 & Phase 2 & $36-45$ & $\mathrm{PF}$ & Healed transverse fracture of anterior right patella \\
\hline 498 & & $26-35$ & $\mathrm{PF}$ & $\begin{array}{l}\text { Rotator cuff disease right and left humeri and } \\
\text { right scapula }\end{array}$ \\
\hline 520 & Phase 2 & $46+$ & $\mathrm{PF}$ & $\begin{array}{l}\text { Healed fracture midshaft left humerus. Healed } \\
\text { fractures } 2 \text { ribs. Osteochondritis dissecans right } \\
\text { and left proximal lateral tibiae }\end{array}$ \\
\hline 585 & Phase 4 & $12-17$ & UN & No pathology \\
\hline 592 & & $26-35$ & $\mathrm{UN}$ & No pathology \\
\hline 626 & Phase 1 & $36-45$ & $\mathrm{~F}$ & No pathology \\
\hline 629 & & $26-35$ & PM & $\begin{array}{l}\text { Healed fracture right mandibular condyle. OA left } \\
\text { mandibular condyle. Periostitis (active) medial } \\
\text { left fibula - non-specific infection }\end{array}$ \\
\hline
\end{tabular}




\begin{tabular}{|c|c|c|c|c|}
\hline 663 & Phase 2 & $6-11$ & UN & No pathology \\
\hline 669 & Phase 3 & $1-5$ & UN & No pathology \\
\hline 684 & & $\mathrm{AD}$ & UN & No pathology \\
\hline 708 & Phase 3 & $26-35$ & $\mathrm{~F}$ & $\begin{array}{l}\text { Transverse fracture of anterior right patella with } \\
\text { non-union }\end{array}$ \\
\hline 714 & Phase 3 & $\mathrm{AD}$ & PM & No pathology \\
\hline 717 & & $6-11$ & UN & No pathology \\
\hline 724 & Phase 2 & $18-25$ & $\mathrm{~F}$ & $\begin{array}{l}\text { Shortening left femur, no evident pathology. } \\
\text { Periostitis lower limbs, non-specific infection }\end{array}$ \\
\hline 733 & & $36-45$ & PM & $\begin{array}{l}\text { Sub-chondral cysts right and left calcaneii, } \\
\text { bilateral pseudo-arthrosis. Rotator cuff disease } \\
\text { right and left humeri }\end{array}$ \\
\hline 736 & & $46+$ & UN & No pathology \\
\hline 742 & Phase 3 & $18-25$ & $\mathrm{PF}$ & No pathology \\
\hline 752 & Phase 1 & $26-35$ & $\mathrm{~F}$ & No pathology \\
\hline 755 & Phase 1 & $26-35$ & UN & No pathology \\
\hline 816 & & $46+$ & PF & OA left hip \\
\hline 825 & Phase 1 & $1-6 \mathrm{MO}$ & UN & No pathology \\
\hline 843 & Phase 1 & $46+$ & PM & United and healing fracture right distal ulna \\
\hline 852 & Phase 4 & $12-17$ & IND & No pathology \\
\hline 868 & Phase 3 & $18-25$ & $\mathrm{~F}$ & Sharp force trauma cranium \\
\hline 883 & Phase 3 & $26-35$ & $\mathrm{~F}$ & $\begin{array}{l}\text { Myositis ossificans trumatica proximal bilateral } \\
\text { tibiae }\end{array}$ \\
\hline 915 & Phase 3 & $\mathrm{AD}$ & UN & No pathology \\
\hline
\end{tabular}


Table 2. Demographic profile of the assemblage of Auldhame skeletons. Age categories utilized: 0 : no ageing data, 1: foetal/neonatal, 2: 1-6 months, 3: 7-11 months, 4: 1-5 years, 5: 611 years, 6: 12-17 years, 7: Young Adults 18-25 years, 8: Middle Adult (A) 26-35 years, 9: Middle Adults (B) 36-45 years, 10: Old adults 46+ years, 11: Adults, 12: Sub-adult.

\begin{tabular}{|c|c|c|c|c|c|c|c|c|c|c|c|c|c|c|}
\hline $\begin{array}{c}\text { Age } \\
\text { Sex }\end{array}$ & 0 & 1 & 2 & 3 & 4 & 5 & 6 & 7 & 8 & 9 & 10 & 11 & 12 & Total \\
\hline Male & 0 & 0 & 0 & 0 & 0 & 0 & 1 & 8 & 19 & 15 & 14 & 2 & 0 & 59 \\
\hline Female & 0 & 0 & 0 & 0 & 0 & 0 & 4 & 4 & 13 & 17 & 7 & 1 & 0 & 46 \\
\hline Intermediate & 0 & 0 & 0 & 0 & 0 & 0 & 1 & 1 & 4 & 5 & 0 & 0 & 0 & 11 \\
\hline Undetermined & 0 & 11 & 8 & 8 & 13 & 20 & 7 & 5 & 6 & 8 & 1 & 31 & 8 & 126 \\
\hline Total & 0 & 11 & 8 & 8 & 13 & 20 & 13 & 18 & 42 & 45 & 22 & 34 & 8 & 242 \\
\hline
\end{tabular}


Table 3. Results of the Strontium and Oxygen isotope analysis on tooth enamel (e), soil (s) and dentine (d) samples from Auldhame. Standard deviations relate to triplicate analyses of each oxygen sample.

\begin{tabular}{|l|l|l|l|l|l|c|}
\hline Sample & $\begin{array}{l}\mathrm{Sr} \\
\mathrm{ppm}\end{array}$ & ${ }^{87} \mathrm{Sr}{ }^{86} \mathrm{Sr}$ & $\delta^{18} \mathrm{O}_{\mathrm{VSMOW}}$ & 1 s.d. & $\delta^{18} \mathrm{O}_{\mathrm{dw}}$ & 1 s.d. \\
\hline AULD-SK-074e & 158 & 0.709926 & 18.1 & \pm 0.17 & -5.8 & \pm 0.37 \\
\hline AULD-SK-122e & 143 & 0.708751 & 17.1 & \pm 0.10 & -8.1 & \pm 0.22 \\
\hline AULD-SK-158e & 92 & 0.713542 & 17.3 & \pm 0.03 & -7.5 & \pm 0.07 \\
\hline AULD-SK-216e & 75 & 0.709339 & 18.2 & \pm 0.04 & -5.8 & \pm 0.09 \\
\hline AULD-SK-219e & 84 & 0.710213 & 17.2 & \pm 0.15 & -7.9 & \pm 0.32 \\
\hline AULD-SK-318e & 85 & 0.709637 & 16.5 & \pm 0.11 & -9.3 & \pm 0.24 \\
\hline AULD-SK-327e & 142 & 0.709484 & 19.0 & \pm 0.12 & -3.9 & \pm 0.26 \\
\hline AULD-SK-352e & 92 & 0.708903 & 16.5 & \pm 0.12 & -9.3 & \pm 0.25 \\
\hline AULD-SK-394e & 140 & 0.709329 & 17.3 & \pm 0.16 & -7.6 & \pm 0.34 \\
\hline AULD-SK-467e & 178 & 0.70939 & 16.9 & \pm 0.08 & -8.5 & \pm 0.17 \\
\hline AULD-SK-520e & 99 & 0.710593 & 16.9 & \pm 0.04 & -8.4 & \pm 0.10 \\
\hline AULD-SK-714e & 128 & 0.710306 & 18.3 & \pm 0.05 & -5.4 & \pm 0.10 \\
\hline AULD-SK-733e & 108 & 0.710841 & 16.8 & \pm 0.08 & -8.6 & \pm 0.18 \\
\hline AULD-SK-742e & 137 & 0.710037 & 17.7 & \pm 0.11 & -6.7 & \pm 0.25 \\
\hline AULD-SK-752e & 168 & 0.709236 & 17.5 & \pm 0.10 & -7.2 & \pm 0.22 \\
\hline Mean & 167 & 0.711162 & 17.5 & \pm 0.08 & -7.1 & \pm 0.18 \\
\hline s.d. & & 0.710043 & 17.4 & \pm 0.09 & -7.3 & \pm 0.21 \\
\hline & & 0.0011 & 0.69 & & 1.5 & \\
\hline
\end{tabular}




\begin{tabular}{|l|l|l|l|l|l|l|}
\hline AULD-SK-216d & 351 & 0.708551 & & & & \\
\hline AULD-SK-883d & 370 & 0.708311 & & & & \\
\hline
\end{tabular}


Table 4. Carbon and nitrogen isotope values for the Auldhame individuals. Mean and Standard deviation does not include 2 individuals with $\mathrm{C} / \mathrm{N}$ ratios $>3.6$

\begin{tabular}{|l|c|c|c|c|c|}
\hline Sample & $\delta^{13} \mathrm{C}_{\mathrm{VPDB}}$ & $\delta^{15} \mathrm{~N}_{\text {AIR }}$ & $\% \mathrm{C}$ & $\% \mathrm{~N}$ & at $\mathrm{C} / \mathrm{N}$ \\
\hline AULD-SK-011 & -20.4 & 10.7 & 45.0 & 15.8 & 3.3 \\
\hline AULD-SK-074 & -18.6 & 12.7 & 41.2 & 14.1 & 3.4 \\
\hline AULD-SK-104 & -20.6 & 10.9 & 34.9 & 11.1 & 3.7 \\
\hline AULD-SK-120 & -19.0 & 13.2 & 43.1 & 15.1 & 3.5 \\
\hline AULD-SK-122 & -20.2 & 10.7 & 42.1 & 14.0 & 3.6 \\
\hline AULD-SK-140 & -19.5 & 13.2 & 42.0 & 14.5 & 3.4 \\
\hline AULD-SK-158 & -18.5 & 14.4 & 37.6 & 12.9 & 3.4 \\
\hline AULD-SK-182 & -19.3 & 11.7 & 38.5 & 12.8 & 3.5 \\
\hline AULD-SK-190 & -19.5 & 12.5 & 48.1 & 16.8 & 3.3 \\
\hline AULD-SK-216 & -20.6 & 11.5 & 39.8 & 13.8 & 3.4 \\
\hline AULD-SK-219 & -21.1 & 11.7 & 43.6 & 14.9 & 3.4 \\
\hline AULD-SK-273 & -19.2 & 11.4 & 38.7 & 13.4 & 3.4 \\
\hline AULD-SK-289 & -20.1 & 13.5 & 44.9 & 15.8 & 3.3 \\
\hline AULD-SK-293 & -19.7 & 11.8 & 38.5 & 13.2 & 3.4 \\
\hline AULD-SK-299 & -19.5 & 11.8 & 40.8 & 14.0 & 3.4 \\
\hline AULD-SK-318 & -19.4 & 13.6 & 43.9 & 14.7 & 3.5 \\
\hline AULD-SK-321 & -19.8 & 12.4 & 43.9 & 15.2 & 3.4 \\
\hline AULD-SK-327 & -17.9 & 13.1 & 44.0 & 15.0 & 3.4 \\
\hline AULD-SK-345 & -19.6 & 11.8 & 43.4 & 14.8 & 3.4 \\
\hline AULD-SK-352 & -20.1 & 12.2 & 40.4 & 14.1 & 3.4 \\
\hline AULD-SK-394 & -20.1 & 11.8 & 44.2 & 15.5 & 3.3 \\
\hline AULD-SK-426 & -18.7 & 12.4 & 35.3 & 11.3 & 3.7 \\
\hline AULD-SK-429 & -20.4 & 11.0 & 44.6 & 15.1 & 3.5 \\
\hline AULD-SK-452 & -19.9 & 11.1 & 41.1 & 13.9 & 3.5 \\
\hline AULD-SK-467 & -18.9 & 12.8 & 42.9 & 15.4 & 3.3 \\
\hline AULD-SK-498 & -19.5 & 11.7 & 49.5 & 17.1 & 3.4 \\
\hline AULD-SK-520 & -19.3 & 14.4 & 43.8 & 15.2 & 3.4 \\
\hline AULD-SK-585 & -19.1 & 12.1 & 45.1 & 15.5 & 3.4 \\
\hline AULD-SK-592 & -19.4 & 12.1 & 41.7 & 14.1 & 3.5 \\
\hline AULD-SK-626 & -18.6 & 13.4 & 45.3 & 15.7 & 3.4 \\
\hline AULD-SK-629 & -19.3 & 11.7 & 49.3 & 17.0 & 3.4 \\
\hline AULD-SK-663 & -18.9 & 13.7 & 47.3 & 16.2 & 3.4 \\
\hline AULD-SK-669 & -18.3 & 12.6 & 36.4 & 12.3 & 3.5 \\
\hline AULD-SK-684 & -20.8 & 11.4 & 41.2 & 14.6 & 3.3 \\
\hline AULD-SK-708 & -18.8 & 13.0 & 43.8 & 15.0 & 3.4 \\
\hline AULD-SK-714 & -19.8 & 11.7 & 35.8 & 11.8 & 3.5 \\
\hline AULD-SK-717 & -19.3 & 14.1 & 43.9 & 15.1 & 3.4 \\
\hline AULD-SK-724 & -19.2 & 12.5 & 43.7 & 15.0 & 3.4 \\
\hline AULD-SK-733 & -19.2 & 14.4 & 44.9 & 15.6 & 3.4 \\
\hline AULD-SK-736 & -20.3 & 12.3 & 44.8 & 15.7 & 3.3 \\
\hline
\end{tabular}




\begin{tabular}{|l|c|c|c|c|c|}
\hline AULD-SK-742 & -19.6 & 11.1 & 43.5 & 15.3 & 3.3 \\
\hline AULD-SK-752 & -19.9 & 11.6 & 44.1 & 15.4 & 3.4 \\
\hline AULD-SK-755 & -20.3 & 10.7 & 43.1 & 14.8 & 3.4 \\
\hline AULD-SK-816 & -20.0 & 11.8 & 44.7 & 15.4 & 3.4 \\
\hline AULD-SK-825 & -21.5 & 10.9 & 40.2 & 13.7 & 3.4 \\
\hline AULD-SK-843 & -20.8 & 10.8 & 40.3 & 13.3 & 3.5 \\
\hline AULD-SK-852 & -19.1 & 13.4 & 43.8 & 14.9 & 3.4 \\
\hline AULD-SK-868 & -19.1 & 12.2 & 37.8 & 13.4 & 3.3 \\
\hline AULD-SK-883 & -19.0 & 12.8 & 42.5 & 14.3 & 3.5 \\
\hline AULD-SK-915 & -19.6 & 13.1 & 40.5 & 14.0 & 3.4 \\
\hline Mean & -19.6 & 12.3 & & & \\
\hline 1 s.d. & 0.73 & 1.03 & & & \\
\hline
\end{tabular}

Table 5. Sulphur isotope values for the Auldhame individuals, 1 s.d. relates to the duplicate analyses.

\begin{tabular}{|c|c|c|c|c|c|c|}
\hline Sample & Sex & $\delta^{34} \mathrm{~S}_{\mathrm{VCDT}}$ & 1 s.d. & $\% \mathrm{~S}$ & at N/S & at C/S \\
\hline AULD-SK-011 & $\mathrm{F}$ & 14.6 & 0.11 & 0.20 & 177 & 586 \\
\hline AULD-SK-120 & $\mathrm{M}$ & 15.1 & 0.04 & 0.23 & 147 & 499 \\
\hline AULD-SK-158 & $\mathrm{M}$ & 14.4 & 0.03 & 0.20 & 151 & 514 \\
\hline AULD-SK-273 & $\mathrm{F}$ & 15.7 & 0.06 & 0.22 & 142 & 478 \\
\hline AULD-SK-289 & $\mathrm{F}$ & 14.8 & 0.48 & 0.21 & 175 & 581 \\
\hline AULD-SK-327 & $\mathrm{M}$ & 11.9 & 0.03 & 0.23 & 156 & 526 \\
\hline AULD-SK-452 & $\mathrm{F}$ & 8.2 & 0.00 & 0.22 & 147 & 507 \\
\hline AULD-SK-626 & $\mathrm{M}$ & 14.8 & 0.04 & 0.21 & 169 & 569 \\
\hline AULD-SK-708 & $\mathrm{M}$ & 11.7 & 0.05 & 0.22 & 155 & 528 \\
\hline AULD-SK-752 & $\mathrm{M}$ & 15.5 & 0.16 & 0.22 & 163 & 545 \\
\hline AULD-SK-868 & $\mathrm{F}$ & 14.6 & 0.42 & 0.22 & 133 & 438 \\
\hline
\end{tabular}


Table 6. Mean carbon, nitrogen and sulphur isotope results from Auldhame over the demographic sample.

\begin{tabular}{|c|c|c|c|c|c|}
\hline & $\mathrm{N}$ & Mean $\delta^{13} \mathrm{C}$ & Mean $\delta^{15} \mathrm{~N}$ & $\mathrm{~N}$ & Mean $\delta^{34} \mathrm{~S}$ \\
\hline Age Groups & & & & & \\
\hline Less than 12 months & 1 & -21.5 & 10.9 & 0 & \\
\hline $1-5$ years & 1 & -18.3 & 12.6 & 0 & \\
\hline $6-11$ years & 2 & -19.1 & 13.9 & 0 & \\
\hline $12-17$ & 3 & -19.4 & 12.6 & 0 & \\
\hline $18-25$ & 6 & -19.4 & 12.1 & 2 & 13.3 \\
\hline $26-35$ & 15 & -17.5 & 12.3 & 5 & 14.4 \\
\hline $26-45$ & 10 & -19.3 & 12.4 & 3 & 12.6 \\
\hline $46+$ & 7 & -20.0 & 12.3 & 1 & 15.1 \\
\hline Sex Groups & & & & & \\
\hline Males & 11 & -20.0 & 11.9 & 6 & 13.9 \\
\hline Females & 19 & -19.2 & 12.6 & 5 & 13.6 \\
\hline
\end{tabular}

Table 7. Mean strontium, oxygen, carbon and nitrogen isotope results per phase of the burial ground. $\mathrm{N}=$ sample numbers per dated phase.

\begin{tabular}{|l|l|l|l|l|l|l|l|l|}
\hline Phase & $\mathrm{N}$ & Mean ${ }^{87} \mathrm{Sr}{ }^{86} \mathrm{Sr}$ & $\mathrm{N}$ & $\operatorname{Mean} \delta^{18} \mathrm{O}$ & $\mathrm{N}$ & Mean $\delta^{13} \mathrm{C}$ & $\mathrm{N}$ & Mean $\delta^{15} \mathrm{~N}$ \\
\hline 1 & 7 & 0.709 & 7 & 17.4 & 14 & -20.2 & 14 & 11.7 \\
& & & & & & & & \\
\hline 2 & 5 & 0.71 & 5 & 16.9 & 8 & -19 & 8 & 13.2 \\
\hline 3 & 6 & 0.709 & 6 & 18.1 & 9 & -18.9 & 9 & 12.4 \\
\hline 4 & 0 & - & 0 & - & 2 & -19.1 & 2 & 12.7 \\
\hline
\end{tabular}

